\title{
БАЛКАНСКИТЕ ВОЈНИ И АКТУЕЛНИТЕ СОСТОЈБИ НА БАЛКАНОТ
}

\author{
МАКЕДОНКА МИТРОВА, МАРИЈА ПАНДЕВСКА
}

\begin{abstract}
: Македонка Митрова, Марија Пандевска, Балканските војни и актуелните состојби на Балканот (The Balkan Wars and the contemporary Balkans).

Balcanica Posnaniensia. Acta et studia, XX, Poznań 2013, Wydawnictwo Instytutu Historii UAM, pp. 105-116, ISBN 978-83-63047-36-1, ISSN 0239-4278. Macedonian text with a summary in English.

Македонка Митрова, Марија Пандевска, Институт за национална историја - Скопје, Република Македонија.
\end{abstract}

\section{1. БАЛКАНСКИТЕ ВОЈНИ: ДОГОВОРИТЕ И ОСВОЈУВАҢАТА}

Популистичката парола со крстоносен призвук: „Да ги ослободиме нашите браќа христијани“, послужила како солидно алиби за експанзионистичките стремежи на младите балкански држави во мобилизирањето на своето население во Првата балканска војна. Различните толкувањата на фразата „браќа христијани“" веќе се наsирале во склучените балкански договори и тајни анекси. Со Втората балканска војна паднале маските и крвавите настани од двете војни (во кои масовно биле протерувани и убивани и христијани и муслимани) отворено ја покажало само желбата кај балканските држави за територијални проширувања. Кој за што тежнеел: Грција за житните полиња на Македонија и Одринско; Бугарија за излез на топлите мориња на Македонија и Одринско; Србија за излез на море по секоја цена, ако не може на Солунскиот Залив, тогаш на Драчкото пристаниште; Црна Гора за Скадарското пристаниште итн. Втората меѓусојузничка војна ја покажала комплетната суштина на различното толкување на т.н. „ослободување“. 1

\footnotetext{
1 За завојувачкиот карактер на Балканските војни пишуваат и следните автори: Х. Р. Викинсон, Картите и политиката:преглед на етнографската картографија на Македонија, Скопје 1992, 183; Холм Зундхаусен, Историја Србије од 19. до 21. века, Београд 2009, 233; Марк Мазовер, Балканот- кратка историја, Скопје 2003, 129-151; Стефан Павловић, Историја Балкана, Београд 2001, 291; Leften Stavrijanos, Balkan posle 1453 godine, Beograd 2005, 508; Latinka Perovi\}, Između anarhije i autokratije: Srpsko društvo na prelazima (XIX-XX), Beograd 2006, 28.
} 
Првиот договор меѓу балканските земји бил потпишан помеѓу Бугарија и Србија во март 1912 година. Односите меѓу двете влади по 1903 година биле подобрени, но тие се́ уште наидувале на тешкотии во постигнувањето договор околу територијалната поделба на османлиска Македонија. Бугарските претставници во овие преговори го поддржувале создавањето на автономна македонска држава, со надеж дека таа на крај би п̃ се приклучила на Бугарија. Наспроти тоа, Србија сакала договор за поделба. Договорот што тогаш бил потпишан само површно претставувал заеднички дефанзивен пакт. ${ }^{2}$

Кон Договорот бил приклучен и таен анекс, со кој се регулирала натамошната судбина на османлиска Македонија. ${ }^{3}$ Во член 2 од тајниот анекс било утврдено идното заедничко координирано дејствување против османлиската држава и решавањето на сите проблеми што ќе искрснеле од таа зедничка акција. Договорените страни утврдиле: сите територијални придобивки од војната со османлиската држава ќе бидат под заедничка власт (кондоминиум) на обете договорнички и нивната ликвидација ќе се извршела веднаш, а најдоцна во рок од три месеца по потпишувањето на мирот. Тоа би се извршило врз основа на правото на Бугарија на територијата источно од Родопите и реката Струма и на Србија на териториите северно и западно од Шар Планина. Што се однесувало до териториите меѓу Шар Планина и Родопите, и Егејското Море и Охридското Езеро т.е. за Македонија, со договорот се предвидувало: ако обете страни бидат уверени во неможноста на давање автономија на таа област, а со оглед на општите интереси на српската и бугарската влада, прашањето со таа територија ќе се уредувало со прецизна, дијагонална линија. Новата граница би била повлечена од Големиот Врв кај Крива Паланка до манастирот Габовци на Охридското Езеро. И со ова всушност била одредена идната можна српско - бугарска граница во османлиска Македонија т.е. во спорната територија за двете држави. Оваа прејудицирана гранична линија во текот на Првата балканска војна против османлиската држава, станала главен проблем меѓу двете сојузнички.

Воената конвенција, која исто така била придодадена кон Договорот, ги содржела взаемните обврски во случај на австро-унгарски напад врз Србија, односно романски врз Бугарија. Истовремено биле утврдени и потребните сили што двете страни требало да ги вложат во борбата против Османлиската Империја. ${ }^{4}$

Склучувањето на српско - бугарскиот договор отворил можност бугарската дипломатија да ги отпочне преговорите за склучување на истоветен дого-

\footnotetext{
2 Јован Донев, Големите сили и Македонија за време на Првата балканска војна, Скопје $1988,55$.

${ }^{3}$ Саво Скоко, Други балкански рат,Узрочи и припрема рата, књ. I, Београд 1968, 106-109; Иван Гешов, Балканският съюзъ. (Спомени и документи), София 1915, 77-80; Соборник договоров Росии с другими государствима 1856-1917, Москва 1952, 113-117; Александар Христов, Јован Донев, Македонија во мегуународните договори 1875-1919, Скопје 1994, 164-166; Петар Стојанов, Македонија во политиката на големите сили во времето на балканските војни 1912-1913, Скопје 1979, 75-77.

${ }^{4}$ Први балкански рат 1912-1913, Београд 1959, 113-117.
} 
вор со Грција. Всушност, во однос кон Грција, бугарската влада морала да го применува истиот став што го применувало и Кралството Србија. Не можело да стане збор за српско - грчко зближување, ако претходно не биле регулирани српско-бугарските односи. „Обидите кои тогаш се правеа со цел да се согласиме со Грција, а разграничувањето на српско-грчките сфери на влијание во Македонија и во Албанија“, пишувал Милован Миловановиќ, „само дадоа нови докази дека за Србија спогодбата со Грција можела да има практична вредност, отткако претходно ќе се утврди српско-бугарската заедница. Бугарите, меѓудругото имаа исти искуства во свои обиди да се договорат со Грција. Причината од една страна е географската положба, што и Србија и Бугарија ги упатувала една на друга и им ги врзува рацете за регулирање на односите со Грција, додека претходно не ги регулираат своите односи. “5

Договорот потпишан на 29 мај 1912 година меѓу Бугарија и Грција покажал дека меѓу нив постои поголем судир за поделбата на османлиска Македонија отколку помеѓу Бугарија и Србија. Поединечното разграничување во османлиска Македонија не било воопшто спомнато, истото било одложено по завршувањето на војната со османлиската држава. ${ }^{6}$

Преговорите меѓу Србија и Грција, започнале на 14 август 1912 година, и не биле завршени до почетокот на војната. Грчката неподготвеност да му помогне на Кралството Србија во случај на напад од Австро-Унгарија, како и недовербата која Србија и Бугарија ја предизвикале кај својата сојузничка, не сакајќи да ја информираат за својот договор за сојуз, ја оневозможиле спогодбата. И покрај ова, помеѓу Србија и Грција бил воспоставен сојузнички однос и одлучност заедно да го решат балканското прашање. ${ }^{7}$

Црна Гора последна се приклучила кон сојузниците. Во средината на септември меѓу Црна Гора и Бугарија дошло до усмени договарања. Договорот помеѓу Србија и Црна Гора бил потпишан на 6 октомври 1912 година во Луцерно, само на два дена пред почетокот на војната. ${ }^{8}$ Со овие договори не било регулирано прашањето за поделбата на „ослободените“ територии.

\footnotetext{
5 Милован Миловановић, „Историк преговора за заклучење српско - бугарског уговора од 29 фебруара 1912“, Српски извори за историјата на македонскиот народ 1912-1914, (гл. редактор Глигор Тодоровски), Скопје 19179, 23-24.

6 За преговорите со Грција види: С. Скоко, Други балкански рат.., 94-95. Осврнувајќи се на ова прашање, бугарскиот политичар, Стојан Данев, ја дал следната изјава: „Всушност, имавме два проблема кои не можевме да ги пребродиме. Првиот беше потребата од времето за такво нешто... За да дојдеме до согласност со Србија, јас ви реков дека со месеци водевме преговори. Немаше никаква причина да претпоставиме дека со Грците полесно ќе ги решиме тие прашања... Второ, ние горе долу чувствувавме дека разграничувањето меѓу нас и Грците ќе биде возможно само ако ние се откажеме од Солун. Во тоа време бугарската влада немаше желба со еден полтички акт да изјави дека се откажува од Солун...“- - Ј. Донев, Големите сили и Македонија..., 59.

7 С. Скоко, Други балкански рат..., 95-97; Први балкански рат 1912-1913, 131-132.

${ }^{8}$ Сî до половината на 1912 година, Србија и Бугарија, одбивале да влезат во преговори со Црна Гора. Причините за ваквиот однос лежел во, од нивната точка на гледање, проавстриската политика на кралот Никола. По анексијата на Босна и Херцеговина од страна на Австро-Унгарија, влада-
} 
Сојузничкото држење на Србија и Бугарија, како и на останатите балкански држави, произлегувало од отворената длабока политичка криза во османлиската држава во почетокот на 1912 година, и претставувала основа за реализирање на нивните интереси. Меѓутоа, само сојузничките односи на балканските држави не биле доволни за влегување во војна. Балканските држави не смееле да влезат во војна, а да бидат претставени како нарушители на мирот, раководени само од сопствените интереси: требало да се војува за цели кои би можеле и морале да бидат верификувани како длабоко оправдани. Напоредно со преговорите и потпишувањето на договорите за формирање на Балканскиот сојуз, во сите балкански држави биле преземени акции за подготвување на јавното мнение за престојната војна.

Преговорите меѓу балканските држави, можеби не до најситни детали, им биле познати на големите сили, кои станувале се́ позагрижени. Тие не сакале уште една источна криза. На 8 октомври Русија и Австро-Унгарија, во име на сите големи сили, испратиле предупредување до балканските држави. Интервенцијата дошла предоцна. ${ }^{9}$ Истиот ден Црна Гора ја нападнала Османлиската Империја. Балканските сојузници веднаш ñ се приклучиле. Така Грција, Бугарија, Србија и Црна Гора за прв пат биле здружени во Балкански сојуз и се бореле заедно против Османлиската Империја.

Победата над османлиската војска била лесна. Балканските сили броеле околу 700.000 војници, наспроти 320.000 луѓе, колку што имал нивниот противник. Османлиската воена сила била ослабена од домашните политички судири и финансиски проблеми поради што војската ја оставиле без модерно оружје. Покрај тоа, за време на војната, грчката флота го контролирала морето, па османлиските трупи не можеле да дојдат од Анадолија до Македонија по најбрзиот и најкраткиот пат. Османлиската влада се плашела од избувнување на еден ваков балкански конфликт и подготвувајќ́ се за настанот, во септември склучила договор со востанатите Албанци, а во октомври и со Италија. ${ }^{10}$ Италијанско - османлиската

та во Цетиње отпочнала да ги подобрува своите односи со Австро-Унгарија, поради што дошло до извесно заладување во нејзините односи со Русија. Токму од овие причини Русија не се согласувала со влегувањето на Црна Гора во Балканскиот сојуз. - Види поопширно: Хенрих Батовски, „Црна Гора и Балкански савез 1912“, Историски записи, бр. 10, Титоград 1957, 47-60.

${ }^{9}$ Руските дипломати верувале дека со Балканскиот сојуз си создале одбранбен блок против Австро-Унгарија, и не очекувале дека овој сојуз ќе влезе во војна против османлиската држава. И затоа биле изненадени кога Балканската лига почнала да ја напаѓа Империјата. „Русија се обидува да закочи“, забележал францускиот премиер Рејмон Поенкаре, „но токму таа е онаа што го запали моторот“. „За прв пат во историјата на Источното прашање“, забележал друг француски дипломат, „малите држави се здобија со позиција на толкава независност од големите сили што се чувствуваат способни да дејствуваат целосно самостојно, па дури и нив да ги повлечат.“ - Leften Stavrijanos, Balkan posle 1453 godine, 510.

10 Во почетокот на 1912 година дошло до големо албанско востание на териториите на Дреница, Пеќ, Ѓаковица и северна Албанија. Востаниците го зазеле целото Косово, северна Албанија, па дури успеале да влезат и во Скопје. Високата Порта во почетокот ги одбивала албанските барања за автономија за да подоцна им вети автономна покраина Албанија. Со овој чин, таа ја испровоцирала војната акција на Балканскиот сојуз насочен против неа. 
војна била започната уште од 1911 година и се водела околу Триполи во Либија. По склучениот османлиско - италијански договор, италијанската влада не само што ги добила Триполи и Киренаика, туку ги искористила Балканските војни како изговор да ги задржи Додеканезите, што ги окупирала претходно. И покрај овие акции, османлиската влада не била подготвена за војна. Иако во претходните години османлиските армии успевале да ги победат балканските воени сили, овој пат комбинацијата била премногу моќна. ${ }^{11}$

Од страна на балканските држави најголемите битки ги водела бугарската војска, која се судрила со главните османлиски сили во Тракија. Бугарската команда била принудена да ги концентрира сите свои напори таму. Во меѓувреме, српските и грчките сојузници напредувале во албанските и македонските подрачја. Црна Гора напредувала кон Скадар, а грчката војска се обидела да ја заземе Јанина. И грчката и бугарската војска брзале накај Солун. На 8 ноември Грците стигнале први, со што ја лишиле Бугарија од главниот македонски град. ${ }^{12}$

Со овој очигледен колапс на османлиското владеење, европските сили побрзале да интервенираат. Во мај 1913 година тие ги принудиле завојуваните страни да прекинат со борбите и да преговараат за условите на мировен договор од Лондон. Со овој договор била воспоставена линијата Енос - Мидија со која се ограничувале османлиските имоти во Европа, кои биле сведени на Цариград и на некои околни територии. На Бугарија í било дадено Едрене; Крит, конечно, í бил отстапен на Грција. ${ }^{13}$ Големиот проблем околу поделбата на Македонија останал. Тука се појавил уште еден проблем што претходно балканските сојузници воопшто и не го предвиделе. Во нивните договори тие настапувале со претпоставка дека меѓусебно ќе ја поделат албанската територија. Наместо тоа, откриле дека големите сили инсистираат да се формира албанската држава. ${ }^{14}$

Главни приврзаници на независна Албанија биле Италија и Австро-Унгарија. Од друга страна, Русија ги поддржувала барањата на балканските држави. Една од основните српски цели во војната било добивање на некое пристаниште на Јадран, по можност Драч. Како и порано, Хабсбуршката Империја, поддржана од Италија, се спротивставила на ширењето на Србија кон Јадранското Море. И овие две големи сили биле цврсто решени да обезбедат создавање на Албанија со цврсти етнички граници, кои би служеле како брана од соседните словенски држави. Со оглед на тоа дека со ваквиот чин и Србија и Грција би биле лишени од територија којашто очекувале да ја освојат, тие како компензација побара-

11 Барбара Јелавич, Историја на Балканот, II, Скопје 1999, 112.

12 За текот и резултатите на балканските војни види: Helmreich Ernst Christian, The Diplomacy of the Balkan Wars, Cambridge/Mass. 1938 (repr. New York 1969); Hall Richard C., The Balkan Wars, 1912-1913, Prelude to the First World War, London 2000.

13 За време на балканската анексионистичка криза (1908-1909), грчкото население од Крит направило обид да го отфрли вазалниот статус и да се придружи кон Грција, но, наишло на отпор од страна на османлиската држава и на големите сили. Критското прашање било решено за време на Балканските војни, односно со Лондонскиот мировен договор.

14 Холм Зундхаусен, Историја Србије од 19. до 20. века, 235. 
ле дел од македонската територија, која се́ уште била „нераспределена“. Не се поставувало воопшто прашањето околу етничкиот карактер на територијата за која станувало збор, туку за рамнотежа на силите меѓу балканските сојузници. ${ }^{15}$ Уште еднаш, плашејќи се од Бугарија како најголем конкурент, Србија и Грција дошле до взаемен таен договор за поделба на односната територија и за заемно помагање во случај на нова војна. ${ }^{16}$ Овие две држави, исто така, биле во постојан контакт со Романија, Црна Гора, па дури и со Османлиската Империја.

Во меѓувреме, ситуацијата станувала се́ понаелектризирана во Софија. Бугарската влада немала намера да отстапи дел од територијата на Македонија на своите сојузнички. Главниот револт бил насочен кон српската држава поради непочитување на Договорот од 1912 година за проектираната гранична линија во Македонија. Бугарија не само што ги предизвикала зависта и непријателството на своите бивши сојузници, туку таа немала ниту поддршка од некоја голема сила. Погрешно проценувајќ ја ситуацијата, убедена дека може да однесе воена победа, ноќта меѓу 29 и 30 јуни 1913 година, Бугарија ги нападнала Грција и Србија. Нападот претставувал катастрофална грешка. Романските, црногорските и османлиските трупи се обединиле во борба против бугарската војска. Втората балканска војна резултирала со целосен пораз на Бугарија. ${ }^{17}$ На 31 јули било потпишано примирје.

Балканските војни предизвикале масовни злосторства над цивилното население. Имено, за прв пат во историјата овие војни биле и медиски покриени, новинарите оделе заедно со војниците и известувале за состојбата на фронтовите. Извештаите за масовните злосторства над цивилното население бргу се ширеле низ светот. Како реакција на тие информации, Карнегиевата фондација испратила посебна комисија на Балканот, која ги истражувала злосторствата и за кои напишала извештај на повеќе од стотина страници. Така, Карнегиевата комисија утврдила дека $80 \%$ од муслиманските села биле запалени од балканските војски. Од ваквите методи не било поштедено ниту христијанското население во Македонија. Биле забележани и случаеви во коишто војските влегувале во селата, ги раздвојувале мажите од жените и децата, па потоа ги убивале по ред, само едната од тие групи или пак и двете. Најчесто овие злосторства ги правеле здружените војници на сојузничките балкански држави. Особено бил забележан случајот во Струмица, кадешто еден српски мајор заедно со тројца бугарски офицери влегувале од куќа во куќа со еден сведок кој ја потврдувал „вината““ на идните жртви. Така, според извештајот на Карнегиевата комисија се смета дека на овој начин биле убиени помеѓу 3 и 4 илјади луѓе во регионот на Струмица. ${ }^{18}$

15 Б. Јелавич, Историја на Балканот, II, 115; Стефан Павловић, Историја Балкана, 291.

${ }^{16}$ L. Stavrijanos, Balkan posle 1453 godine, 513.

17 Б. Јелавич, Историја на Балканот, II, 115-116; Katrin Bozeva-Abazi, The shaping of Bulgarian and Serbian National Identities, 1800-1900, Skopje 2007, 220.

18 Поранешните балкански војни (1912-1913), извештај на Карнегиевата балканска комисија, Скопје 2000, 106. 
Со Букурешкиот договор од август 1913 година, Македонија била поделена меѓу некогашните сојузнички. Така, големи победнички станале Србија и Грција. Со добивањето на македонската и косовската територија, Србија станала речиси двојно поголема. Црна Гора и Србија го поделиле Новопазарскиот Санџак што Хабсбуршката Монархија го вратила по анексијата на Босна и Херцеговина. Со тоа двете држави обезбедиле заедничка граница. Грција ја добила Јужна Македонија и дел од Епир, со градот Јанина. Грчката граница на исток била проширена и ја вклучила Кавала. И покрај поразот, Бугарија добила територија околу долината на реката Струма и 128 километри од егејскиот брег, вклучително и пристаништето Дедеагач. И Османлиската Империја и Романија добиле територии: Портата го вратила Едрене, а Романија ја добила Јужна Добруџа. Крајниот договор, како што може да се види, претставувал огромен чекор назад за Бугарија и за Османлиската Империја. ${ }^{19}$

Така, двете балкански војни го докрајчиле османлиското владеење на Полуостровот, освен во појасот на Тракија и во Цариград. Османлиската власт не била способна да го запре натамошното пропаѓање на Империјата. ${ }^{20}$

\section{2. МАКЕДОНСКОТО И КОСОВСКОТО ПРАШАЬЕ: НЕЗАВРШЕНИ ИСТОРИСКИ ПРОЦЕСИ}

Балканските војни 1912-1913 година, кои траеле во еден краток временски интервал, помал од година дена, оставиле тешки последици кај балканските народи. Турција овие војни ги доживеела како најголема траума во својата модерна историја, губење на своите најзападни и најразвиени европски провинции. Оваа незадоволство во турскиот јавен политички дискурс е присутно и претставува важен „квасец“ на модерниот национализам во земјата.

Во бугарскиот случај, траумата е уште поголема. Овие настани, покрај „неправедниот“ Берлински договор кога бил „поделен единствениот бугарски народ“, биле доживувани, а и до ден денес се интерпретираат како поделба на „бугарското национално ткиво“, како предавство на сојузниците, на прво место на Србија, која по таа логика земала дел од „бугарската територија“ (се мисли на Македонија). Ова претставува извор на трајно незадоволство и национална фрустрација во Бугарија.

Албанците со Балканските војни доживеале голема промена. На Лондонската мировна конференција, била создадена независна албанска држава. Меѓутоа, со одлуките на големите сили на конференцијата, територијата на Косово, припаднала на Кралството Србија. Ваквата постапка создала длабока фрустрација во албанското национално движење, затоа и денеска, во јавниот дискурс и во

19 Б. Јелавич, Историја на Балканот, II, 116.

20 С. Павловић, Историја Балкана, 292. 
Косово и во Албанија присутно е мислењето дека со неправедната одлука на големите сили, албанскиот народ во 1913 година бил поделен. ${ }^{21}$

По Балканските војни, грчката држава и покрај тоа што земала најголем дел од македонската територија била незадоволна поради делбата на северен Епир со новосоздадената албанска држава. Додека, пак, националистичкиот албански дискурс не го заборава јужниот дел на Епир како територија која останала надвор од матичната земја.

Балканските војни во историската меморија кај Македонците имаат посебно болна и фрустрирачка улога. Истите се перцепираат како најдобар доказ за грабливоста на соседните народи чиишто „национални интереси“ биле формулирани на сметка на македонската територија. Втората балканска војна се водела исклучиво за поделба на македонската територија, и истата завршила со Букурешкиот мировен договор, со кој била санкционирана поделбата на Македонија и тоа на Вардарска, Пиринска и Егејска Македонија помеѓу Србија, Бугарија и Грција. ${ }^{22}$

Со политичката поделба на Македонија од 1913 година завршил словенскиот, македонски етнички период и започнал периодот на десловенизација и демакедонизација на македонскиот етничко - историски простор. Процесот на десловенизација и демакедонизација се забележуваат во егејскиот дел на Македонија, процеси на демакедонизација, но со словенизација со туѓ (српски) етнички елемент се забележуваат во вардарскиот дел на Македонија, а процеси на промена на етничкиот состав на населението не биле забележани во пиринскиот дел на Македонија. Но, затоа бугарската влада, македонските бегалци ги населувала во различните делови низ целата територија на бугарската држава врз кои потоа лесно можела да изведе асимилација. Интензитетот и размерите на овие текови и процеси на колонизација и асимилација биле различни во егејскиот, вардарскиот и пиринскиот дел на Македонија. ${ }^{23}$

Така, неизбежна е констатацијата дека Балканските војни преставувале матрица на национални фрустрации кај балканските народи кои во нив учествувале. „Ваквото болно искуство низ кое поминале балканските народи покажало дека државните граници добиени преку војна никого не задоволиле. Особено таа реалност била доста далеку од замислените државни граници кои биле засновани на концептот на 'историски права'. Имено, секоја балканска нација, својот национален сон го врзувала со средниот век кога нивните држави ја достигнале максималната големина. За нереалноста на овој концепт не заостанувале ни оние кои се повикувале на 'етничко начело'. Имено, на етнички измешаниот балкански простор, особено во ситуација кога сите нации не биле во голема мерка формирани, не било можно да се повлече граница

${ }^{21}$ Dubravka Stojanovic, Ulje na vodi:ogledi iz istorije sada\{njosti Srbije, Beograd 2010, 260-261.

22 За ова види: Стојан Киселиновски, Етничките промени во Македонија (1913-1995), Скопје $2000,29$.

23 Истото. 
која секого би задоволила и којашто подоцна не би предизвикала незадоволство и ирендентизам.“24

Впрочем првата цел на балканските војски била да се прошират границите на националните држави за сметка на Османлиската Империја и заедно со старата држава да замине и муслиманското население од Балканот. Оваа емпирија всушност била дел од претходните воени искуства на балканските земји. Имено, после Големата источна криза, кога Србија добила големо територијално проширување на југ, околу 70.000 припадници на муслиманската вера, меѓу кои, во голем број биле Албанците, ги напуштиле овие територии. ${ }^{25}$ Мнозинството од овие Албанци ја населиле територијата на Косово, каде се одмаздувале на локалните Срби, поради нивното прогонување од териториите кои припаднале на Србија. ${ }^{26}$ Во 1913 година, кога Косово било приклучено на српската држава, ова ќе се сврти против нив. Така, германскиот историчар Х. Зундхаусен констатирал дека на тој начин започнал ѓаволскиот круг на меѓусебно прогонување кој ќе ги означи српско - албанските односи во следниот век. ${ }^{27}$ После Балканските војни, Србија станала повеќеетничка држава и својата територија ја проширила кон југо - запад и исто така добила околу 1,3-1,4 милион нови жители. Косово приближно имало околу 600.000 а Македонија околу 800.000 жители. И во двата случаја, Србите биле малцинство. Од населението во Косово скоро три четвртини говорело албански. ${ }^{28}$ После воените судири, се смета дека околу 20.000 Албанци го изгубиле животот, и дека побегнале околу 60.000 припадници на муслиманската вера. ${ }^{29}$ Односите меѓу српското и албанското население биле трајно нарушени, а довербата подоцна никогаш не била воспоставена. Поради ова, историската меморија била важен фактор во судирите на Косово во текот на деведесеттите години на 20 век. Меѓудругото, мора да се акцентираат и денешните комплексни српско - албански односи на Балканот, со создавањето на независна држава Косово во 2008 година, како и новиот политички однос меѓу Албанија, Македонија, Србија и самото Косово. Исто така важно е да се потенцира дека Романија и Грција, некогашните сојузнички на српската држава во Втората балканска војна, сі̂ уште ја немаат признаено независноста на Косово.

По Букурешкиот договор, грчката држава од скоро етнички хомогена станала повеќеетничка држава. Поголемиот дел од населението што живеело во егејскиот дел на Македонија по Балканските војни било од негрчко потекло. Според јазикот што се зборувал во домот, т.е. во семејството, во тој дел на Македонија

\footnotetext{
24 D. Stojanovic, Ulje na vodi: ogledi, 262.

25 Х. Зундхаусен, Историја Србије, 156; Бранислав Нушиќ, Косово, Опис земле и народа, Београд 1986, 76-77.

${ }^{26}$ Радован Самарџић, Сима М. >ирковић, Олга Зиројевић, Радмила Тричковић, Душан Т. Батаковић, Веселин Ђуретић, Коста Чавошки и Атанасије Јевтић, Косово и Метохија у српској историји, Београд 1989, 217.

27 Х. Зундхаусен, Историја Србије, 155.

28 Истото. 236.

${ }^{29}$ Истото. 238.
} 
живееле 370. 371 или 35, 20 \% македонско население, 274. 052 или $25.05 \%$ турско население, 236.755 или 22, 50 \% грчко население, 68. 206 или 6,49\% еврејско население, 44. 414 или 4, 22\% влашко население итн. Значи од вкупно 1. 052. 227 жители, 77, 50\% биле негрци и само 236.755 или 22, 50\% биле Грци по потекло и мајчин јазик. ${ }^{30}$ Но, ставајќ́ го во темелот на својата држава принципот „таму каде што сме ние, нема место за друг“, грчката држава веднаш по 1913 година почнала да спроведува политика за создавање држава со една нација и еден јазик. Затоа, по Букурешкиот договор, Грција почнала да ја реализира политиката на протерување на македонското население и колонизирање на немакедонско население со цел да се измени традиционалниот македонски етничко - историски лик во егејскиот дел на Македонија. ${ }^{31}$ Поради овие причини националното незадоволство од Балканските војни, денеска ги оптоварува и грчко - македонските односи. Со распаѓањето на Југословенската федерација, Република Македонија во 1991 година прогласи независност и со тоа стана самостоен политички субјект на меѓународната сцена. Но, нејзиното интегрирање во НАТО и Европската Унија е спречено од нејзиниот јужен сосед. Проблемот со грчкото непризнавање на уставното име на македонската држава, всушност лежи токму во овој Букурешки договор. Грчката држава успеа преку механизмите на своите институции да создаде нов регионален грчко - македонски идентитет во северниот дел од својата земја, односно во оној историски дел од османлиска Македонија кој успеа да го освои со Балканските војни. Впрочем, проблемот на непризнавањето на македонското малцинство во Република Грција е латентно присутен во оспорувањето на името на Република Македонија од страна на грчката држава. Овој проблем, всушност е од есенцијално значење во решавањето на спорот меѓу двете држави. ${ }^{32}$ Грчката државна политика преку непризнавањето на македонското малцинство во својата земја, јасно покажува дека го оспорува и постоењето на македонската нација. Од друга страна пак, бугарската држава ја призна Република Македонија под нејзиното уставно име но, одбива да го признае постоењето на македонската нација и јазик. Така, бугарската власт доследна на својата политика, не го признава и македонското малцинство во својата земја.

Сите овие политички реалности наведуваат на констатацијата дека нерешените политички прашања, како македонското и косовското, може да имаат долго историско траење и тоа од еден цел век. Тоа не значи дека историјата се повторува бидејќ таа никогаш не може да биде иста. Прекинатите процеси на национално - политичкиот развој ( како кај Македонците ) може да бидат успорени, но не можат да бидат прекинати: тоа се само историски процеси на дол-

30 Васил Кънчов, Македония - Етнография и статистика, София 1900, 289. - преземено од С. Киселиновски, Етничките промени, 30.

31 С. Киселиновски, Етничките промени, 30.

32 За ова види: Спорот за името меѓ Гриија и Македонија, (гл. редактори: Светомир Шкариќ, Димитар Апасиев и Владимир Патчев), Скопје 2008. 
го траење. Замрзнатите конфликти и нерешените прашања се сѐ уште товар за Балканот и придонесуваат неговата политичка култура да се менува многу споро и тешко.

\title{
ЗАКЛУЧОК
}

Суштината на сите балкански конфликти концизно ја има дефинирано Марија Тодорова кога напишала: „практично никој не го истакнува фактот дека етничките конфликти не ги предизвикува етничката комплексност сама по себе, туку етничката комплексност во рамките на идеализираната национална држава, којашто, се стреми кон етничката хомогеност. “33 И навистина прашањето за малцинствата од секогаш било составен дел од развојот на националните држави, а особено во Југоисточна Европа. Притоа, пожелно е да се потенцира фактот дека националните револуции на Балканот претставувале израз на влијанието на националните движења во Централна или Западна Европа. Значи моделот на една нација - една држава на Балканот се пресликува токму под влијание на западната идеологија. Впрочем, Европа му ги дала на Балканот, категориите со кои неговите народи се дефинираат себеси, но исто така му го дала и идеолошкото оружје - пред се́ во формата на модерниот романтичарски национализам, кој во континуитет предизвикува меѓусебни непочитувања, сомнежи, стравови, судири, и уништувања. Токму затоа што процесот на градење нација е понов и позбиен на Балканот, етничкиот национализам останува посилен, а граѓанските традиции покршливи. Единствена историска перспектива за Балканот во 21 век за надминување на историските трауми и предрасуди претставува развојот на цивилното општество и развојот на економската соработка како заемно поврзан регион на ниво на сите комуникации.

\section{THE BALKAN WARS AND THE CONTEMPORARY BALKANS}

\author{
Summary
}

A populist slogan, with a crusade like overtones: "to liberate our Christian brothers", served as an unassailable alibi for the expansionist aspirations of the small Balkan states in order to mobilize their population during the First Balkan War. The different interpretations of the phrase "Christian brothers" could already be seen in the Balkan pacts and their hidden annexes. The Second Balkan War quite openly revealed the sole objective of the Balkan states for territorial expansion in those wars. To each his own:

${ }^{33}$ Марија Тодорова, Замислувајки го Балканот, Скопје 2001, 189. 
Greece longed for the wheat fields of Macedonia and Edirne; Bulgaria longed for the warm seas of Macedonia and Edirne; Serbia longed to be a coastal country at any cost- if they could not reach the Salonika Bay, then through the Durres port; Montenegro longed for the Skhodër (Skadar/Shkodra) port, etc. The Second Balkan War proved to be the quintessence of different interpretation of the word "to liberate".

Even though the Balkan Wars lasted for almost a year (between 1912 and 1913), they left the Balkan people with severe consequences. Namely, since the Balkan territory was ethnically diverse, especially in a period when not all of the nations were yet completely defined, it was not possible to draw the state lines which could please everybody and which would not dissatisfy the population later. Thus, the same actors would actively participate in both World Wars. Because of this, the discontentment originating in the period of the Balkan Wars still burdens the relations between the Balkan countries to this day. The unresolved political questions, such as the problem of Macedonia and Kosovo, may have lasted the whole century. This, however, does not mean that history repeats itself, because history can never be the same. Frozen conflicts and unresolved issues still burden the Balkans and contribute to the very slow and hard development of its political culture. 